
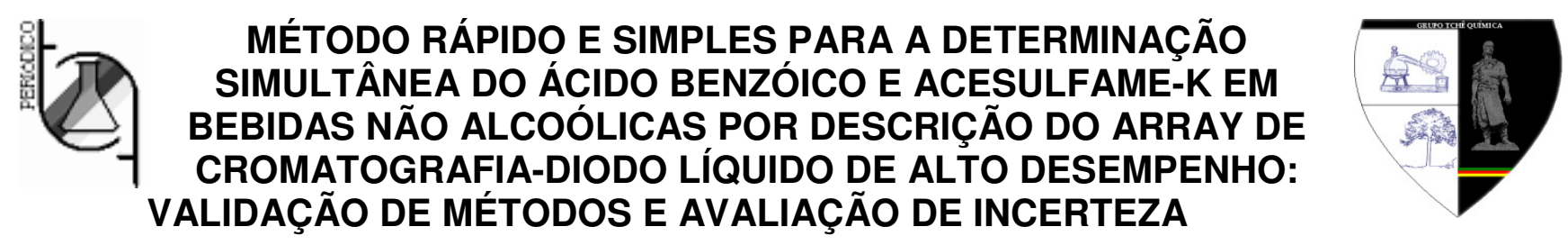

\title{
FAST AND SIMPLE METHOD FOR SIMULTANEOUS DETERMINATION OF BENZOIC ACID AND ACESULFAME-K IN SOFT DRINKS BY HIGH PERFORMANCE LIQUID CHROMATOGRAPHY-DIODE ARRAY DETECTOR: METHOD VALIDATION AND UNCERTAINTY EVALUATION
}

\author{
PUTRI, Dillani ${ }^{1 *}$; ARISTIAWAN, Yosi ${ }^{1}$; ARYANA, Nurhani ${ }^{1}$ and STYARINI, Dyah ${ }^{1}$ \\ ${ }^{1}$ Metrology in Chemistry Laboratory, Research Center for Metrology, Indonesian Institute of Sciences, Kawasan \\ PUSPIPTEK, Building 420, Serpong, 15314 Tangerang Selatan, Banten, Indonesia
}

(Phone: +62 21756 0533; fax: +62 21756 0568)

* Corresponding author

e-mail: dill001@lipi.go.id

Received 28 April 2017; received in revised form 25 September 2017; accepted 22 October 2017

\section{RESUMO}

Classificados como aditivos alimentares, o uso de ácido benzóico e acesulfame $\mathrm{K}$ para preservar alimentos é finito devido à razões de saúde e meio ambiente. Neste estudo, um método eficiente e rápido para a determinação simultânea de ácido benzóico e acesulfame-K em refrigerantes foi validado usando alto desempenho cromatografia líquida com detector de matriz de diodos (HPLC-DAD) em uma coluna C18. O método mostrou resultados satisfatórios uma vez que o coeficiente de determinação do ácido benzóico e acesulfame-K foi 0,9998 e 0,9991 , respectivamente. O LOD para ambos os compostos encontrados em 0,02 $\mathrm{mg} / \mathrm{kg}$ e a LOQ foram encontrados em 0,07 e $0,06 \mathrm{mg} / \mathrm{kg}$ para ácido benzóico e acesulfame-K, respectivamente. Os estudos de recuperação demonstraram que o método tem uma boa recuperação variando de 96 a 103\% tanto para o ácido benzóico quanto para o acesulfame-K com \%RSD variando de 1,6 a 4,6\% em diferentes concentrações. O método validado foi então aplicado à amostra de comparação entre laboratórios realizada pelo Laboratório de Controle de Qualidade Nacional para Drogas e Alimentos (NQCLDF), na Indonésia, utilizando materiais de referência padrão rastreáveis. A avaliação da incerteza com abordagem de baixo para cima mostrou que o método possui um valor de incerteza razoável com o orçamento de incerteza derivado do processo de pesagem, estudos de recuperação, precisão do método, curva de calibração e solução padrão. O valor de incerteza ( $k=2$, no nível de confiança de $95 \%)$ para o ácido benzóico foi de $4 \%$ na concentração relatada de $343 \mathrm{mg} / \mathrm{kg}$ e para o acesulfame-K foi de $6,5 \%$ na concentração de $195 \mathrm{mg} / \mathrm{kg}$. Em suma, o método validado ofereceu um método simples e rápido, bem como o consumo econômico de reagentes, indicando sua possível aplicação como método alternativo para uma análise de rotina.

Palavras-chave: Ácido benzóico, acesulfame-K, refrigerante, HPLC, validação, incerteza

\section{ABSTRACT}

Classified as food additives, the use of benzoic acid and acesulfame $\mathrm{K}$ to preserve foods is finite due to health and environmentreason.In this study, anefficient and fast method for simultaneous determination of benzoic acid and acesulfame-K in soft drinks was validated using high performance liquid chromatography with diode array detector (HPLC-DAD) on a C18 column. The method showed results satisfaction as the coefficient determination for benzoic acid and acesulfame-K were 0.9998 and 0.9991 respectively. The LOD for both compounds found at $0.02 \mathrm{mg} / \mathrm{kg}$ and the LOQ were found at 0.07 and $0.06 \mathrm{mg} / \mathrm{kg}$ for benzoic acid and acesulfame-K respectively. The recovery studies proved that the method has a good recovery ranging from 96$103 \%$ for both benzoic acid and acesulfame-K with \%RSD varies from $1.6-4.6 \%$ at different concentrations. The validated method then applied to the inter-laboratory comparison sample conducted by the National Quality 
Control Laboratory for Drug and Food (NQCLDF), Indonesia, using traceable standard reference materials. Uncertainty evaluation using bottom-up approach showed that the method has reasonable uncertainty value with uncertainty budget derived from weighing process, recovery studies, method precision, calibration curve and standard solution. The uncertainty value $(k=2$, in confidence level $95 \%)$ for benzoic acid was found to be $4 \%$ at reported concentration of $343 \mathrm{mg} / \mathrm{kg}$ and for acesulfame- $\mathrm{K}$ was found to be $6.5 \%$ at reported concentration of $195 \mathrm{mg} / \mathrm{kg}$. In conclusion, the validated method offered a simple and fast method, as well as economical reagents consumption indicating its possible application as an alternative method for a routine analysis.

Keywords: Benzoic acid, acesulfame-K, soft drink, HPLC, validation, uncertainty

\section{INTRODUCTION}

According to the U.S. Food and Drug Administration (FDA), food additive is any substance with its intended results or may reasonably be expected to affecting the characteristics of any food (U.S. Food and Drug Administration, http://www.fda.gov). Based on its use, food additives can be divided into six categories including preservatives (such as antimicrobials, antioxidants and anti-chemical change), nutritional additives (vitamins, minerals, fibers), flavoring agents (sweeteners, natural or synthetic flavor enhancers), coloring agents, texturing agents (such as emulsifiers and stabilizers) and miscellaneous additives (include enzymes, solvents and catalyst) (Branen and Haggerty, 2002; Kritsunankul and Jakmunee, 2011). In several food processing, more than one food additive are usually added to improve the quality. For example in low calories beverages, many additives are added with the purposes to enhance food flavor, prevent from spoilage and also to control the calories intake (Diogo et al., 2013; Roberts, 2016; Sylvetsky and Rother, 2016).

Benzoic acid and its sodium salts are widely used for food preservatives to prevent microbial growth or chemical change. Benzoic acid is simple aromatic carboxylic acid compound and presents naturally in many plants. Industrially, benzoic acid is obtained as a byproduct during the liquid phase oxidation process of toluene with air as an oxidant and acetic acid as solvent (Humayun et al., 2016). The estimated global production capacity for benzoic acid is about 600000 ton per year and maximum allowable concentration of benzoic acid as food additive was reported to be $2000 \mathrm{mg} / \mathrm{kg}$ (WHO, 2000).

Acesulfame-K is an artificial sweetener commonly added to food and often blended with other sweeteners (usually sucrose or aspartame) to control the sweetness of food especially beverage, soft drink and dietary product. The acceptance daily intake (ADI) for acesulfame-K according to FDA is $15 \mathrm{mg} / \mathrm{kg}$ body weight per day. Among the artificial sweeteners, acesulfame- $K$ has caused more concern due to its wide application, persistence and may easily accumulated in environment (Gan et al., 2014).

Soft drink itself has become popular beverage consumed by all ages around the world. Nowadays consumers demand on safe, flavorful, affordable and long-storage soft drink, which made the use of preservative to extend the storage and the sweeteners to control flavor are unavoidable in soft drink production. Therefore, analytical methods for determining those additives are need to continuously improve to provide accurate and reliable results. Providing accurate analytical data is essential to control presence of the additive under the maximum allowable level, especially in Indonesia so that it can be used to promote the food safety to the consumers. One of significant factor in the providing the accurate analytical results in soft drink analysis is the use of analytical traceable standard reference materials. The traceability of the standard used can give more reliable analysis results, including the more precise-measurement uncertainty evaluation and this information can be very useful to the stakeholder related to the food safety or quality assurance. In Indonesia, Badan Pengawas Obatdan Makanan-BPOM RI (The National Agency of Drug and Food ControlNADCF) is a regulatory body which authorized and supervised the use of additives in food. The NADCF stipulates the maximum concentration for both benzoic acid and acesulfame- $K$ in the soft drink at $400 \mathrm{mg} / \mathrm{kg}$ and $600 \mathrm{mg} / \mathrm{kg}$ respectively (NADCF regulatory No. 30 2013; NADCF regulatory No. 34 2014).

In some previous studies, the methods for the determination of additives in soft drink have been developed and established. These methods 
include capillary electrophoresis (Frazier et al., 2000; Bergamo et al., 2011), UV-Vis spectrophotometry (Chen and $\mathrm{Ni}, 2009$ ), gas chromatography (Pan et al., 2005; Lopez et al., 2015) and liquid chromatography (Wrobel and Wrobel, 2007; Wasik et al., 2007; Kusi and Acquaah, 2014; Quirós et al., 2009; Ma et al., 2012). The liquid chromatography has become widely used for additives analysis due to its sensitivity, easy preparation and relatively low cost. The present study describes the development of a simple method for simultaneous determination of benzoic acid and acesulfame- $K$ in soft drinks using high performance liquid chromatography equipped with diode array detector (HPLC-DAD). The single laboratory method validation and uncertainty evaluation of sample measurement were studied to evaluate the method performance. The sample measurement results then submitted for determining the assign value through the inter-laboratory comparison together with NQCLDF and Thailand Institute of Scientific and Technological Research (TISTR), Thailand. These assigned values were used for proficiency testing scheme program organized by NQCLDF, which is the laboratory under NADCF.

\section{MATERIALS AND METHODS}

\subsection{Materials}

In this study, all chemicals used were analytical grade. The standard certified reference materials (CRM) for benzoic acid (99.99\% purity) was purchased from Health Sciences Authority (HSA), Singapore and the acesulfame-K standard used (100.41\% purity) was from NQCLDF, Indonesia. The CRM's were used in all experiment. Methanol (HPLC grade) and phosphoric acid (85\% purity) were purchased from Merck (Germany). Ultrapure water with resistivity $18 \mathrm{M} \Omega$ was produced using Milli-Q 185 (Merck Millipore) and was used in all experiment runs.

\subsection{HPLC-DAD Analysis}

The instrument system used in this study was HPLC e2695 equipped with a diode array detector DAD 2998 (Waters, United States). The chromatographic separation was performed in Phenomenexhypersil $5 \mu \mathrm{m} \mathrm{C18}$ column with dimension $150 \times 4.8 \mathrm{~mm}$. The isocratic elution using $0.1 \%$ phosphoric acid and methanol (50:50) as mobile phase was used and the flow rate was kept at $1 \mathrm{ml} / \mathrm{min}$ for total runtime of 17 minutes. The single wavelength at $230 \mathrm{~nm}$ was selected for the measurement of the absorbance. The injection volume was $10 \mu \mathrm{l}$ and the column temperature was maintained at $30^{\circ} \mathrm{C}$.

\subsection{Sample Preparation}

The sample used under this study was an Inter-laboratory comparison sample which prepared and supplied by The National Quality Control Laboratory for Drug and Food (NQCLDF), Indonesia. The quick and easy samples preparation was applied for the analysis using HPLC-DAD system. The soft drink samples were degassed using ultrasonic bath for 10 minutes, then diluted gravimetrically about 20 times with methanol. The samples were then filtered using PTFE $0.22 \mu \mathrm{m}$ filter (Agilent) before HPLC-DAD analysis.

\subsection{Method Validation}

\subsubsection{Analytical Standards}

All analytical standards were prepared by gravimetrically dilution method. The each standard was dissolved in methanol to produce a $5000 \mathrm{mg} / \mathrm{kg}$ (ppm) stock solution for both benzoic acid and acesulfame-K. The stock solutions were diluted to about $100 \mathrm{ppm}$ standard solutions. Afterwards, the $100 \mathrm{ppm}$ standard solutions were further diluted to obtain a series of working standard mixture with approximately concentration range as follows: 1, 5, 10, 20, 30, 40 and $50 \mathrm{ppm}$.

\subsubsection{LOD, LOQ and Linearity Study}

For the limit of detection (LOD) and limit of quantitation (LOQ) study, several blank samples solution were spiked with working standard to give a series of spiked blank sample solution having concentration ranging from 0.01 to 0.6 ppm. Moreover, the linearity study of working range for benzoic acid and acesulfame were determined by a calibration curve using a multipoint method (11 points) with the concentration range between 1 to $100 \mathrm{ppm}$.

\subsubsection{Recovery and Precision}

The precision and recovery of the method were evaluated using the blank sample which 
spiked by pure standard solutions at different level of concentrations (before dilution) both for benzoic acid and acesulfame-K. The spiked concentration levels of benzoic acid were 70 , 150,200 and $600 \mathrm{ppm}$, while for the acesulfame$\mathrm{K}$ were 400 and $600 \mathrm{ppm}$. The recovery measurement was conducted with ten replicates for each concentration level. The precision of the instrument was carried out by injecting nine replicationsof the working standard $(20 \mathrm{ppm})$ of benzoic acid and acesulfame-K separately.

\subsection{Uncertainty Evaluation}

The uncertainty of measurement was evaluated using bottom up approach based on JCGM 100.2008 (ISO GUM, Guide to the expression of uncertainty in measurement) and EurachemCitac Guide CG 42012 (Quantifying Uncertainty in Analytical Measurement). The sources of uncertainty used for the evaluation were derived from the following data: weighing process, method precision, calibration curve, standard solution and recovery study.

\section{RESULTS AND DISCUSSION}

\subsection{Method Optimization}

In a practical experiment, optimization of the HPLC's operating conditions to obtain a good separation of the target compounds is extremely important. In this study, the optimum separation of the benzoic acid and acesulfame- $K$ was obtained by the optimization of the HPLC operating condition including the mobile phase, composition of mobile phase, wavelength, runtime and column (oven) temperature. The isocratic elution was chosen to give proper stability since the both compounds show a similar polarity. The pKa of benzoic acid was 4.76 , while the benzoic acid is in its undissociated form in the $\mathrm{pH}$ range of 2.0-4.0 (Kritsunankul and Jakmunee, 2011). Therefore, the stability of the mobile phase was maintained by using a $0.1 \%$ phosphoric acid solution ( $\mathrm{pH} 2$ ). In addition, good sensitivity and resolution for both target compounds were found at wavelength $230 \mathrm{~nm}$ under studied wavelength range i.e., 205-240 nm. Under aforementioned HPLC condition, the analysis results show a good separation of the target compounds both in standard solution and sample as shown in Figure 1 , where the retention time of acesulfame- $\mathrm{K}$ and benzoic acid were found at $1.26 \mathrm{~min}$ and 2.83 min, respectively.

\subsection{Method Validation}

An external multi point calibration technique was applied for the instrument calibration and the data were used to construct the calibration curve for sample analysis. The linearity of the detector response was evaluated by analyzing a set of eleven point calibration solutions which concentration ranging from 1 to $100 \mathrm{ppm}$. It showed a good linearity with $R^{2}$ 0.9993 and 0.9998 for benzoic acid and acesulfame-K, respectively. The LOQ for benzoic acid and acesulfame- $\mathrm{K}$ were 0.07 and $0.06 \mathrm{ppm}$ respectively with LOD was $0.02 \mathrm{ppm}$ for both compounds. In addition, the results showed that the method used in this study has an adequate stability as summarized in Table 1.

The method recovery and precision were evaluated by conducting the recovery study in different days. As can be seen from Table 2, the recovery of benzoic acid gave satisfying results with value around $96-103 \%$, while the recovery of acesulfame- $\mathrm{K}$ in concentrations 400 and 600 ppm also gave satisfying results at about 102 and $96 \%$ respectively. These results meet the criteria of AOAC Appendix F: Guidelines for Standard Method Performance Requirements as it is stated that recommended acceptable recovery for range concentration of $100-1000 \mathrm{ppm}$ is $90-107 \%$. The relative standard deviation (RSD) for all concentrations was also meet the criteria as the RSD was found to be smaller than $5.3 \%$ (AOAC, 2016). For evaluating the instrument precision, a 20 ppm working standard was injected with nine replications and its peak area was analyzed. The results showed that the RSD for peak area of benzoic acid and acesulfame-K were 0.5 and $1.1 \%$ respectively. The manual procedure usually sets that the RSD of instrument drift was not more than $3 \%$. This relatively small RSD indicated that the measurement was conducted under precise equipment condition so that can give the accurate results.

Table 2. The recovery and RSD for benzoic acid and acesulfame- $K$ at different concentrations

\begin{tabular}{llll}
\hline Compound & $\begin{array}{l}\text { Concentration } \\
(\mathrm{mg} / \mathrm{kg})\end{array}$ & $\begin{array}{l}\text { Recovery } \\
(\%)\end{array}$ & $\begin{array}{l}\text { RSD } \\
(\%) \\
\mathrm{n}=10\end{array}$ \\
\hline Benzoic acid & 70 & 96.5 & 1.6 \\
& 150 & 96.2 & 2.0 \\
& 200 & 102.0 & 1.8 \\
& 600 & 103.8 & 4.3 \\
Acesulfame-K & 400 & 102.3 & 2.0 \\
& 600 & 96.0 & 4.6 \\
\hline
\end{tabular}


The two tailed student's $t$-test was conducted to evaluate whether the mean recovery was significantly different from 1 (t $\mathrm{t}_{\text {calc }} \geq$ $t_{\text {crit). }}$. This test can give an appropriate data to advise whether the recovery factor should be applied to the calculation of the sample results. The recovery factor usually explicitly included in the result calculation if the recovery value was significantly different from 1 (EURACHEM,2012). The $t$ value was calculated using Equation 1.

$t=\left|\frac{\left(\bar{x}_{-100) \sqrt{ }}\right.}{s}\right|$

Where:

$\bar{x} \quad$ : average of calculated recovery $(\%)$

s : : measurement's standard deviation (\%)

$\mathrm{n} \quad$ : number of measurement

This $t$ value was then compared with critical $t$ value at $\mathrm{n}-1$ degree of freedom with confidence level of $95 \%$. The results in Table 3 showed that the mean recovery for both benzoic acid and acesulfame- $K$ were not significantly different from 1 as the calculated $t$ were smaller than the critical $t$.

Table 3. The t-test results for mean recovery

\begin{tabular}{|c|c|c|c|c|c|}
\hline Compound & $n$ & $\begin{array}{l}\text { Mean } \\
\text { Recovery } \\
(\%)\end{array}$ & $\begin{array}{l}\text { SD } \\
(\%)\end{array}$ & $t_{\text {calculated }}$ & $t_{\text {critical }}$ \\
\hline $\begin{array}{l}\text { Benzoic } \\
\text { acid }\end{array}$ & 40 & 99.6 & 4.2 & 0.602 & 2.023 \\
\hline $\begin{array}{l}\text { Acesulfame- } \\
\mathrm{K}\end{array}$ & 20 & 99.2 & 4.6 & 0.778 & 2.093 \\
\hline
\end{tabular}

\subsection{Sample Analysis and Uncertainty evaluation}

The sample was analyzed using the validated method. For accurate results, the sample was analyzed in three different days with five replications each day. The RSD for sample measurement was found to be $3.2 \%$ for benzoic acid and $3.6 \%$ for acesulfame- $K$. The concentration of the sample was then calculated using simple equation as describe in Equation 2.

$C_{X}=C_{\text {hplc }} \times \frac{W_{\text {Final }}}{\text { Wsample }}$

Where:

$\mathrm{C}_{\mathrm{x}}$ : final concentration of samples $(\mathrm{mg} / \mathrm{kg})$ $\mathrm{C}_{\text {hplc }}$ : concentration obtained from calibration curve $(\mathrm{mg} / \mathrm{kg})$
$\mathrm{W}_{\text {final }}:$ mass of sample after dilution $(\mathrm{g})$ $\mathrm{W}_{\text {sample }}$ : mass of sample before dilution $(\mathrm{g})$

The results and its uncertainty value are shown in Table 4, as the concentration of benzoic acid reported at $343 \mathrm{mg} / \mathrm{kg}$ and acesulfame- $\mathrm{K}$ at $195 \mathrm{mg} / \mathrm{kg}$. This value was used in the determination of assigned value in interlaboratory comparison together with NQCLDF and TISTR. The assigned value then used for proficiency testing scheme organized by NQCLDF (BPOM RI, 2015).

Table 4. Reported concentration of benzoic acid and acesulfame- $K$

\begin{tabular}{lll}
\hline Compound & $\begin{array}{l}\text { Reported } \\
\text { concentration } \\
(\mathrm{mg} / \mathrm{kg})\end{array}$ & $\begin{array}{l}\text { Uncertainty } \\
(\mathrm{mg} / \mathrm{kg})\end{array}$ \\
\hline Benzoic acid & 343 & 14.1 \\
Acesulfame-K & 195 & 12.5 \\
\hline
\end{tabular}

The uncertainty of samples measurement was evaluate based on JCGM 100.2008 and EurachemCitac Guide CG 4 2012. The components considered supplying the significant contribution to the uncertainty as listed in Table 5 were quantified and combined to give the combined uncertainty $\left(u_{c}\right)$ based on Equation 3.

$$
\begin{array}{r}
u_{c}(x)=C_{x} \sqrt{\left(\frac{u_{m 1}}{m_{1}}\right)^{2}+\left(\frac{u_{m 2}}{m_{2}}\right)^{2}+\left(\frac{u_{\text {chplc }}}{C_{\text {hplc }}}\right)^{2}+\left(\frac{u_{\text {rec }}}{R e c}\right)^{2}+\left(\frac{u_{\text {precision }}}{1}\right)^{2}+\left(\frac{u_{\text {cstd }}}{C_{\text {std }}}\right)^{2}} \\
\text { (Eq. 3) }
\end{array}
$$

The combined uncertainty was multiplied by coverage factor $k=2$ (corresponding to confidence level of $95 \%$ ) to value the expanded uncertainty $(U)$ of the measurement (Vanatta and Coleman, 2007; Konieczka and Namiesnik, 2010). The components of uncertainty included in the evaluation such as weighing process, method precision, calibration curve, standard solution and recovery are listed in Table 5.

The expanded uncertainty of samples measurement for benzoic acid and acesulfame-K were found to be 14.1 and $12.5 \mathrm{mg} / \mathrm{kg}$ respectively, so that give the percentage of the uncertainty $4.1 \%$ for benzoic acid and $6.5 \%$ for acesulfame-K. The budget uncertainty for each component can be seen in Table 6 for benzoic acid and Table 7 for acesulfame-K. These uncertainties of measurement values were 
sufficiently acceptable in comparison to that of the precision values for concentration $400 \mathrm{mg} / \mathrm{kg}$ and $200 \mathrm{mg} / \mathrm{kg}$ derived from the Horwitz function which is 6.4 and $7.2 \%$ respectively (Heyden and Verbeke 2007).

\section{CONCLUSIONS}

A simple and low reagents consumption method for simultaneous determination of benzoic acid and acesulfame-K in soft drink with acceptable uncertainty was well developed by using HPLC-DAD. The LOD, LOQ and linearity studies showed this method could cover a wide range measurement with accurate results through the traceability to the HSA (Singapore) and NQCLDF(Indonesia) certified reference material standards for benzoic acid and acesulfame-K respectively. The recovery of this method gave satisfied results as for benzoic acid the mean recovery was $99.6 \%$ and for acesulfame- $\mathrm{K}$ was $99.2 \%$. The bottom-up approach for uncertainty evaluation based on ISO GUM and EURACHEM showed the measurement in samples gave uncertainty about $4 \%$ for benzoic acid and $6.5 \%$ for acesulfame-K. These uncertainty values are acceptable in comparison to that of the uncertainty derived from Horwitz function. The present method can be proposed for an alternative method in routine laboratory analysis.

\section{ACKNOWLEDGMENTS}

The authors highly appreciate the financial support from the Indonesian Institute of Sciences (Indonesia). The authors also thank NQCLDF and TISTR for the support and kind cooperation during the inter-laboratory comparison. Dillani Putri wishes to thank Dr. Oman Zuas for his generous and continuing advice.

\section{REFERENCES}

1. AOAC Official Methods of Analysis, Appendix F: Guidelines for Standard Method Performance Requirements, 2016.

2. Ashley, R., Physiol. Behav, 2016 164(B), 439.

3. Bergamo, A.B., Silva, J.A.F., Jesus, D.P., Food Chem, 2014, 124, 1714.

4. Branen, A.L., Haggerty, R.J., In: Branen, A.L., Davidson, P.M., Salminen, S.,
Thorngate, J.H., (Eds.) Food Additives, 2nd edn. Marcel Dekker Inc, New York,2002,pp 1 - 11.

5. Chen, Y.Q., Ni, Y.N., Chin. Chem. Lett, 2009, 20, 615.

6. Diogo, J.S.G., Silva, L.S.O., Pena, A., Lino, C.M., Food Chem. Toxicol, 2013, 62, 548.

7. EURACHEM / CITAC Guide CG 4, Quantifying Uncertainty in Analytical Measurement: third edition, 2012.

8. Frazier, R.A., Inns, E.L., Dossi, N., Ames, J.M., Nursten, H.E., J. Chromatogr. A, 2000, 876, 213.

9. Gan, Z., Sun, H., Wang, R., Hu, H., Zhang, P., Ren, X., Water Res, 2014, 64,113.

10. Heyden, Y.V., Verbeke, J.S., J. Chromatogr. A, 2007, 1158, 158.

11. Humayun, H.Y., Shaarani, M.N.N.M., Warrior, A., Abdullah, B., Salam,M.dA.,Procedia Engineering, 2016,148,1320.

12. JCGM 100:2008, Evaluation of measurement data - Guide to the expression of uncertainty in measurement: first edition, 2008.

13. Konieczka, P., Namiesnik, J., J. Chromatogr. A, 2010, 1217, 882.

14. Kritsunankul, O.,Jakmunee, J., Talanta, 2011, 84, 1342-1349.

15. Kusi, J.K., Acquaah, S.O., IOSR J. Env. Sci., Toxicol. and Food Tech. (IOSRJESTFT), 2014, 8(12), 36.

16. Lopez, P., Sisseren, M., Marco, S.D., Jekel, A., Nijs, M., Mol, H.G.J., Food Chem, 2015, 174, 407.

17. Ma, K., Yang, Y.N., Jiang, X.X., Zhao, M., Cai, Y.Q., Chin. Chem. Lett, 2012, 23, 492.

18. National Quality Control Laboratory of Drug and Food, Indonesia, Determination Benzoic acid and Acesulfame- $\mathrm{K}$ in Soft Drink. Report: Proficiency Testing 2015 Food laboratory,2015,Jakarta:BPOM RI.

19. Pan, Z., Wang, L., Mo, W., Wang, C., Hu, W., Zhang, J., Anal. Chim. Acta, 2005, $545,218$. 
20. Quirós, A.R.B, Arias, M.F., Hernández, J.L., Food Chem, 2009, 116, 509.

21. Sylvetsky, A.C., Rother, K.I., Physiol. Behav, 2016, 164(B), 446.

22. The National Agency of Drug and Food Control Republic of Indonesia, regulatory No. 30: maximum limit for preservatives in food, 2013, Jakarta.

23. The National Agency of Drug and Food Control Republic of Indonesia, regulatory No. 34: maximum limit for sweeteners in food, 2014, Jakarta.

24. U.S. FOOD \& DRUG ADMINISTRATION, http://www.fda.gov/Food/IngredientsPack agingLabeling/FoodAdditivesIngredients/, Accessed on 23 August 2016.

25. Vanatta, L.E., Coleman, D.E., J. Chromatogr. A, 2007, 1158, 47.

26. Wasik, A., McCourt, J., Buchgraber, M., J. Chromatogr. A, 2007, 1157, 187.

27. World Health Organization, Concise international chemical assessment document (CICAD) No. 26: Benzoic Acid and Sodium Benzoate, 2000, Geneva:World Health Organization.

28. Wrobel, K., Wrobel. K., J. Chromatogr. A, 1997, 773, 163. 

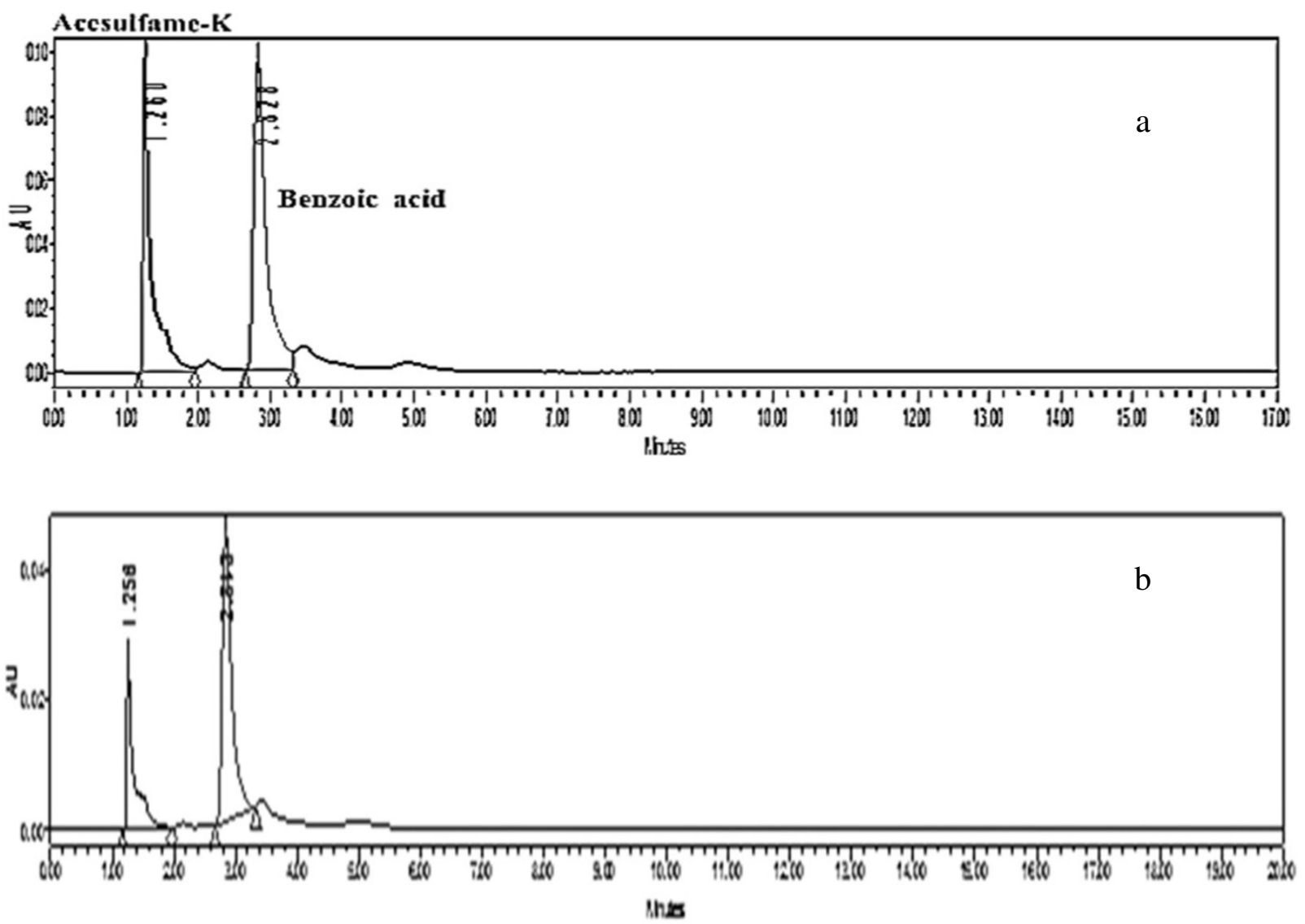

Figure 1. Chromatogram of (a) 20 ppm standard solution mixture containing benzoic acid and acesulfame-K and (b) sample (both at wavelength $230 \mathrm{~nm}$ )

Table 1. The Linearity range, $L O D$ and $L O Q$ of the validated method

\begin{tabular}{lllllllll}
\hline Compound & $\begin{array}{l}\mathrm{Rt} \\
(\mathrm{min} .)\end{array}$ & $\begin{array}{l}\lambda_{\max } \\
(\mathrm{nm})\end{array}$ & $\begin{array}{l}\text { Working } \\
\text { Range } \\
(\mathrm{mg} / \mathrm{kg})\end{array}$ & $\begin{array}{l}\mathrm{R}^{2} \text { for } \\
\text { Working } \\
\text { Range }\end{array}$ & $\begin{array}{l}\text { Linear } \\
\text { Range } \\
(\mathrm{mg} / \mathrm{kg})\end{array}$ & $\begin{array}{l}\mathrm{R}^{2} \text { for } \\
\text { Linear } \\
\text { Range }\end{array}$ & $\begin{array}{l}\mathrm{LOD} \\
(\mathrm{mg} / \mathrm{kg})\end{array}$ & $\begin{array}{l}\mathrm{LOQ} \\
(\mathrm{mg} / \mathrm{kg})\end{array}$ \\
\hline Benzoic acid & 2.83 & 230 & $1-50$ & 0.9998 & $1-100$ & 0.9993 & 0.02 & 0.07 \\
Acesulfame-K & 1.26 & 230 & $1-50$ & 0.9991 & $1-100$ & 0.9998 & 0.02 & 0.06 \\
\hline
\end{tabular}


Table 5. Components of uncertainty for determination of benzoic acid and acesulfame-K using HPLC$D A D$

\begin{tabular}{|c|c|c|}
\hline $\begin{array}{l}\text { Component of } \\
\text { uncertainty }(u)\end{array}$ & Source of uncertainty data & Type \\
\hline$m_{1}$ & $\begin{array}{l}\text { Uncertainty from the mass of sample (based on } \\
\text { calibration certificate of analytical balance) }\end{array}$ & $B$ \\
\hline $\mathrm{m}_{2}$ & $\begin{array}{l}\text { Uncertainty from the mass of sample's final dilution } \\
\text { (based on calibration certificate of analytical } \\
\text { balance) }\end{array}$ & B \\
\hline $\mathrm{C}_{\text {hplc }}$ & $\begin{array}{l}\text { Uncertainty from the concentration obtained from } \\
\text { calibration curve (linear least square fitting } \\
\text { procedure) }\end{array}$ & A \\
\hline Recovery & $\begin{array}{l}\text { Uncertainty from recovery study on the blank spiked } \\
\text { sample (based on mean recovery) }\end{array}$ & A \\
\hline Precision & $\begin{array}{l}\text { Uncertainty from RSD of ten independent analysis of } \\
\text { samples }\end{array}$ & A \\
\hline Standard solution & $\begin{array}{l}\text { - Uncertainty from purity value of the pure } \\
\text { standards used for calibration (based on standard } \\
\text { certificate) } \\
\text { - Uncertainty from the calibration certificate of the } \\
\text { analytical balance used in preparing the standard } \\
\text { and calibration solutions }\end{array}$ & $\begin{array}{l}B \\
B\end{array}$ \\
\hline
\end{tabular}

Table 6. Uncertainty budget for measurement of benzoic acid in soft drink

\begin{tabular}{llllll}
\hline No & Source of uncertainty & Value & $\begin{array}{l}\text { Standard } \\
\text { uncertainty }(u)\end{array}$ & Unit & $\begin{array}{l}\text { Relative } \\
\text { uncertainty (\%) }\end{array}$ \\
\hline 1 & Weighing $_{1}$ & 0.039 & $2.12132 \mathrm{E}-05$ & $\mathrm{~g}$ & 0.054 \\
2 & Weighing $_{2}$ & 0.84 & $2.12132 \mathrm{E}-05$ & $\mathrm{~g}$ & 0.003 \\
3 & Precision & 1 & 0.010066866 & & 1.007 \\
4 & Calibration curve & 16.445 & 0.153152928 & $\mathrm{mg} / \mathrm{kg}$ & 0.931 \\
5 & Recovery & 0.996 & 0.014230251 & & 1.429 \\
$6 \quad$ Standard solution & 21.042 & 0.050210625 & $\mathrm{mg} / \mathrm{kg}$ & 0.239 \\
& & & & \\
\hline Sample concentration & & 343 & $\mathrm{mg} / \mathrm{kg}$ & \\
Combined uncertainty $(u)$ & & 7.0 & $\mathrm{mg} / \mathrm{kg}$ & \\
Expanded uncertainty $(\mathrm{k}=2)$ & & 14.1 & $\mathrm{mg} / \mathrm{kg}$ & \\
\% of uncertainty & & 4.1 & $\%$ & \\
\hline
\end{tabular}


Table 7. Uncertainty budget for measurement of Acesulfame-K in soft drink

\begin{tabular}{llllll}
\hline No & Source of uncertainty & Value & $\begin{array}{l}\text { Standard } \\
\text { uncertainty }(u)\end{array}$ & Unit & $\begin{array}{l}\text { Relative } \\
\text { uncertainty } \\
(\%)\end{array}$ \\
\hline $1 \quad$ Weighing $_{1}$ & 0.039 & $2.12132 \mathrm{E}-05$ & $\mathrm{~g}$ & 0.054 \\
2 & Weighing $_{2}$ & 0.84 & $2.12132 \mathrm{E}-05$ & $\mathrm{~g}$ & 0.003 \\
$3 \quad$ Precision $_{4} \quad$ Calibration curve & 1 & 0.009946206 & & 0.995 \\
$5 \quad$ Recovery & 9.050 & 0.267489963 & $\mathrm{mg} / \mathrm{kg}$ & 2.956 \\
$6 \quad$ Standard solution & 0.992 & 0.004666753 & & 0.470 \\
& 17.695 & 0.097112094 & $\mathrm{mg} / \mathrm{kg}$ & 0.549 \\
\hline $\begin{array}{l}\text { Sample concentration } \\
\text { Combined uncertainty }(u)\end{array}$ & & 195 & $\mathrm{mg} / \mathrm{kg}$ & \\
Expanded uncertainty $(\mathrm{k}=2)$ & & 6.3 & $\mathrm{mg} / \mathrm{kg}$ & \\
\% of uncertainty & & 12.6 & $\mathrm{mg} / \mathrm{kg}$ & \\
\hline
\end{tabular}

PERIÓDICO TCHÊ QUÍMICA • www.periodico.tchequimica.com • Vol. 15 N. 29.

• ISSN 1806-0374 (impresso) • ISSN 1806-9827 (CD-ROM) • ISSN 2179-0302 (meio eletrônico) (C) 2018. Porto Alegre, RS. Brasil

The Periódico Tchê Química (ISSN: 1806-0374; 2179-0302) is an open-access journal since 2004. Journal DOI: 10.52571/PTQ. http://www.tchequimica.com. This text was introduced in this file in 2021 for compliance reasons.

() The Author(s)

OPEN ACCESS. This article is licensed under a Creative Commons Attribution 4.0 (CC BY 4.0) International License, which permits use, sharing, adaptation, distribution, and reproduction in any medium or format, as long as you give appropriate credit to the original author(s) and the source, provide a link to the Creative Commons license, and indicate if changes were made. The images or other third-party material in this article are included in the or exceeds the permitted use, you will need to obtain permission directly from the copyright holder. To view a copy of this license, visit http://creativecommons.org/licenses/by/4.0/. 